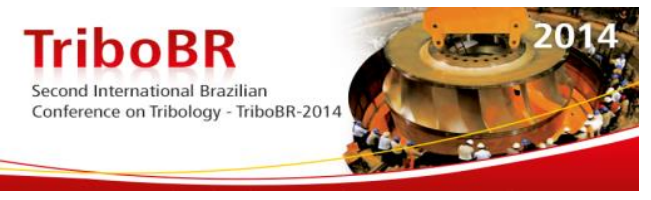

\title{
THE INFLUENCE OF THE NORMAL LOAD AND GRIT SIZE ON THE ABRASIVE WEAR OF POLYMERIC MATERIALS USED IN MINING INDUSTRY*
}

\author{
Lionel Loïc Limol' \\ Davi Andrade Fagundes ${ }^{2}$ \\ Vinicius Varnier Schmitberger ${ }^{2}$ \\ Marcelo Camargo Severo de Macêdo ${ }^{3}$ \\ Cherlio Scandian ${ }^{3}$
}

\begin{abstract}
Polymeric materials, such as polyurethanes and rubbers, are widely used in the mining industry because of their moderate cost and excellent mechanical properties. Such polymers have been used mainly in transportation (conveyor belt systems and pipes coatings) and screening, for their appreciable abrasion wear resistance. Studies revealed the complex influence of test parameters, such as grit size and applied normal load, on the abrasion wear process for polymers. In this study, the abrasive wear behavior of several polyurethanes and rubbers were investigated at room temperature according to a rotary drum abrasion method (DIN 53516). Wear tests were carried out at $26 \mathrm{~cm} / \mathrm{s}$ test speed and load value of $5 \mathrm{~N}$ and $10 \mathrm{~N}$. Corundum paper grit varying from 60 to 400 mesh were used as an abrasive surface. After each test the mass loss of the pin was recorded and the wear rates were calculated from wear volume. The wear surfaces were investigated by scanning electron microscopy.
\end{abstract}

Keywords: Wear; Abrasive grit size; Normal load; Polymer.

1 MSc Student, Mechanical Engineering Department, Federal University of Espírito Santo, Vitória, Espírito Santo, Brazil.

2 B.S. Student, Mechanical Engineering Department, Federal University of Espírito Santo, Vitória, Espírito Santo, Brazil.

3 Dr., Professor, Mechanical Engineering Department, Federal University of Espírito Santo, Vitória, Espírito Santo, Brazil.

* Technical contribution to the $2^{\text {nd }}$ International Brazilian Conference on Tribology - TriboBR 2014, November $3^{\text {rd }}$ to $5^{\text {th }}$, 2014, Foz do Iguaçu, PR, Brazil. 


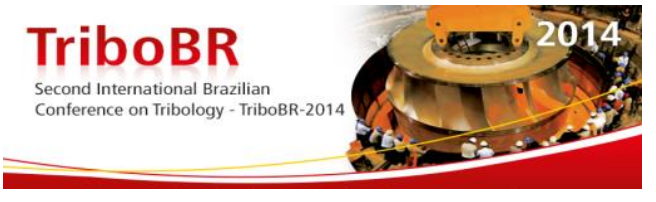

\section{INTRODUCTION}

Wear is an alteration of a solid surface by progressive loss of material due to relative motion between that surface and a contacting substance [1]. Wear leads to increased clearances between moving components, loss of precision and often vibration [2]. The direct and indirect costs generated by wear in the developed countries are approximately between 1 and $5 \%$ of the gross national product [3]. According to Eyre [4], half of wear situations encountered in industrial plants are abrasive processes.

In mining and mineral processing industries, polymeric materials undergo aggressive environments and usually suffer wear. Such abrasive wear situations are encountered in transportation (conveyor belts or pipes coating) and screening (ore screens).

Polymeric materials are mainly used for their good abrasion resistance which is due to their capacity of being flexible enough and to its inability to fracture the grits and to produce fresh sharp edges during the wear motion $[5,6]$.

Despite widespread and growing use of elastomers in engineering applications where abrasion is present, wear of these materials is ill-understood [7]. Due to the fact that polymers have a different mechanical behavior than metals, wear parameters such as load, grit size and sliding distance have been of great interest for engineering applications and investigated by Unal, Zaamout e Srinath [6-8].

Misra and Finnie [9] report that for small abrasives, the wear rate of metals increases proportionally with the increase in the abrasive grit size until it reaches a critical grit size (about $100 \mu \mathrm{m})$. Such behavior was also noticed for stiff polymer such as PMMA [10].

The objective of this work was to study the influence of the grit size on the two-body dry wear rate of elastomeric materials such as polyurethanes and rubbers (directly extracted from new and used parts of mining components) according to a rotary drum abrasion method [11]. Wear tests were carried out at $26 \mathrm{~cm} / \mathrm{s}$ test speed and load value of $5 \mathrm{~N}$ and $10 \mathrm{~N}$. Corundum paper grid varying from 60 to 400 mesh were used as an abrasive surface and surface asperity height distribution has been obtained from contact type stylus profilometry.

Finally, the wear surfaces were investigated by scanning electron microscopy.

\section{MATERIAL AND METHODS}

\subsection{Material}

The cylindrical testing samples were produced according to DIN 53516 from parts of mining components after being cut with an appropriate tool. Characteristics and properties of the samples are presented in Table 1 and Table 2.

The Deerfos abrading papers of grit P60, P120, P180, P240, P400 (Figure 1) were purchased from commercial stocks of the Toro Abrasivos and EPI's and used in the as-received condition.

\footnotetext{
* Technical contribution to the $2^{\text {nd }}$ International Brazilian Conference on Tribology - TriboBR 2014, November $3^{\text {rd }}$ to $5^{\text {th }}$, 2014, Foz do Iguaçu, PR, Brazil.
} 


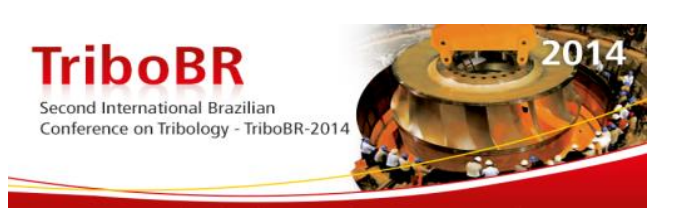

Table 1. Characteristics and Properties of the Polyurethane Samples

\begin{tabular}{lccccc}
\hline $\begin{array}{l}\text { Sample } \\
\text { identification }\end{array}$ & Origin & $\begin{array}{l}\text { State } \\
(\mathrm{mm})\end{array}$ & Diameter & $\begin{array}{c}\text { Density } \\
\left(\mathrm{kg} / \mathrm{m}^{3}\right)\end{array}$ & $\begin{array}{c}\text { Shore A } \\
\text { hardness }\end{array}$ \\
\hline PU1 & $\begin{array}{c}\text { Inside iron ore steel } \\
\text { pipe coating }\end{array}$ & used & $16 \pm 0,2$ & 1063 & 79 \\
\hline PU2 & $\begin{array}{c}\text { Inside iron ore steel } \\
\text { pipe coating }\end{array}$ & new & $16 \pm 0,2$ & 1101 & 79 \\
\hline PU3 & Iron ore screen & used & $16 \pm 0,2$ & 1204 & 81 \\
\hline PU4 & $\varnothing$ & new & & 1057 & 87 \\
\hline PU5 & $16 \pm 0,2$ & & 1127 & 79 \\
\hline
\end{tabular}

Table 2. Characteristics and Properties of the Rubber Samples

\begin{tabular}{lccccc}
\hline $\begin{array}{l}\text { Sample } \\
\text { identification }\end{array}$ & Origin & $\begin{array}{l}\text { State } \\
(\mathrm{mm})\end{array}$ & Diameter & $\begin{array}{c}\text { Density } \\
\left(\mathrm{kg} / \mathrm{m}^{3}\right)\end{array}$ & $\begin{array}{c}\text { Shore A } \\
\text { hardness }\end{array}$ \\
\hline Rub1 & Conveyor belt & new & $16 \pm 0,2$ & 1144 & 74 \\
\hline Rub2 & Conveyor belt & used & $16 \pm 0,2$ & 1139 & 76 \\
\hline Rub3 & Conveyor belt & used & $16 \pm 0,2$ & 1143 & 79 \\
\hline Rub4 & Belt drum coating & new & $16 \pm 0,2$ & 1109 & 67 \\
\hline Rub5 & $\begin{array}{c}\text { ASTM D5963 standard } \\
\text { Rubber \#1 [11]. }\end{array}$ & new & $16 \pm 0,2$ & 1345 & 62 \\
\hline
\end{tabular}
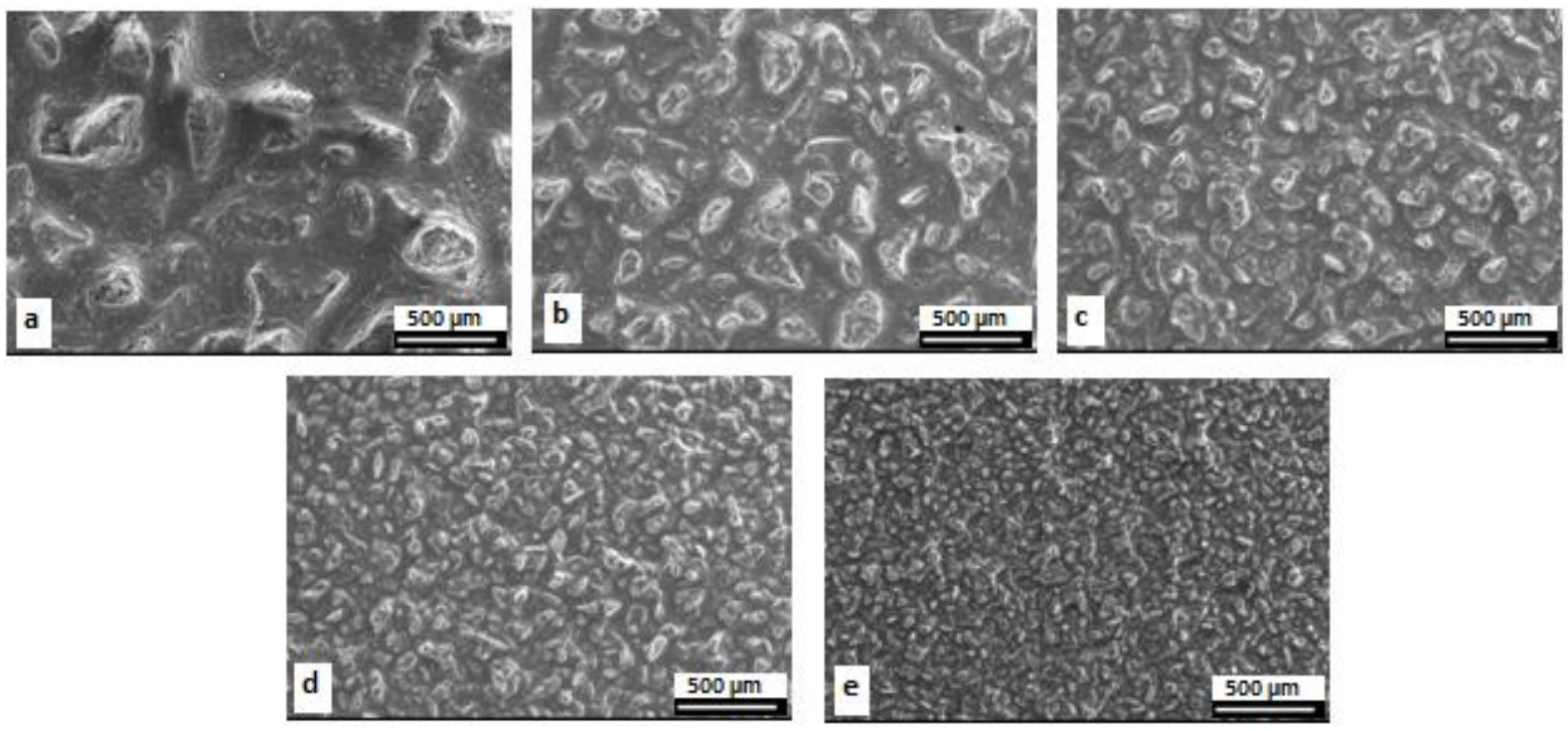

Figure 1. Scanning electron micrographs of the abrasive surface for different grits: (a) P60; (b) P120; (c) P180; (d) P240; (e) P400.

\subsection{Methods}

The experiments were performed in the Laboratory of Tribology, Corrosion and Materials (TRICORRMAT), in the Laboratory of Fuel and Combustion (LCC) at UFES and in the Laboratory of Surface Phenomenon (LFS) at USP, using a Veb Thüringer rotary drum abrasion apparatus (Figure 2) and a Politerm HT-6510A Shore A durometer.

\footnotetext{
* Technical contribution to the $2^{\text {nd }}$ International Brazilian Conference on Tribology - TriboBR 2014, November $3^{\text {rd }}$ to $5^{\text {th }}$, 2014, Foz do Iguaçu, PR, Brazil.
} 

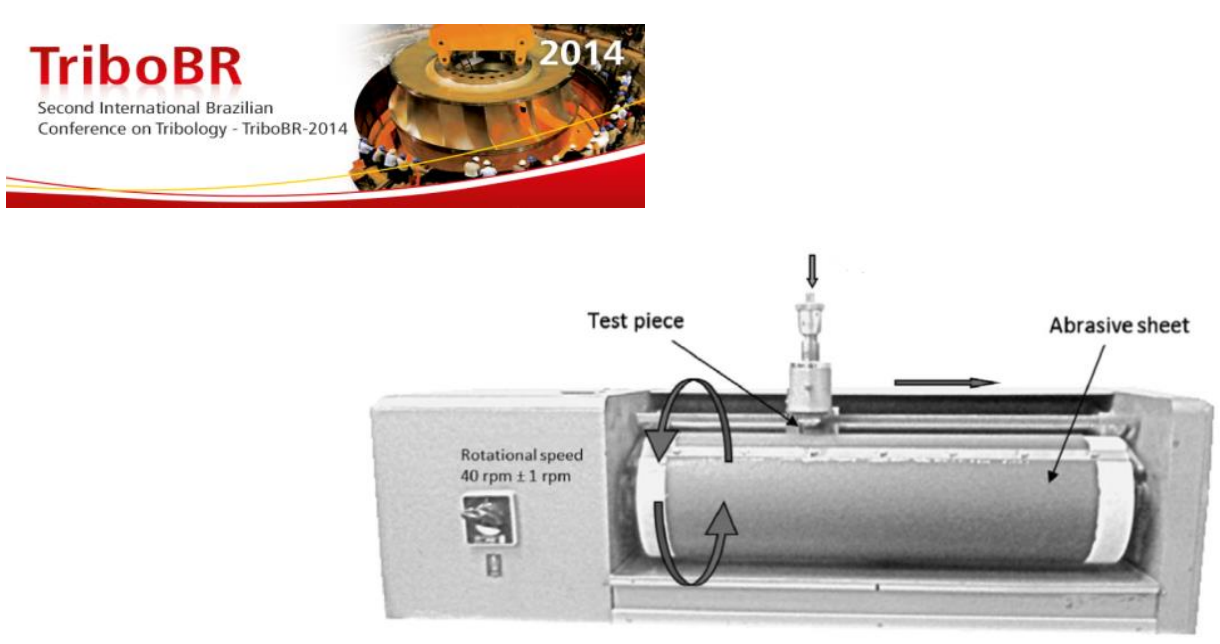

Figure 2. Rotating cylindrical roller device.

After the extraction of the testing samples from parts of mining components, they were cleaned manually with water and neutral soap tribological tests.

For each material, three samples have been tested to obtain nominal loss of mass.

The wear tests were performed at room temperature $\left(23 \pm 3{ }^{\circ} \mathrm{C}\right.$ and humidity $46 \pm 6 \%$ ) with a $26 \mathrm{~cm} / \mathrm{s}$ test speed (which corresponds to a drum rotation of $40 \mathrm{rpm}$ ) and load value of $5 \mathrm{~N}$ and $10 \mathrm{~N}$. After each test the mass loss of the pin was recorded and the wear rates were calculated from wear volume.

Determination of the density was performed according to ASTM D792 and the determination of the Shore A hardness according to ASTM D 2240.

Worn surfaces and abrasive papers were analyzed by scanning electron microscopy (SEM). Contact type stylus profilometry (Taylor-Hobson Talysurf CLI1000) of the abrasive papers were performed. The surface height distribution was calculated from contact type stylus profilometry (Figure 3). From the surface height distribution, the mean of the surface asperities height was computed to highlight a clear relation between wear and abrader grit (Table 3).

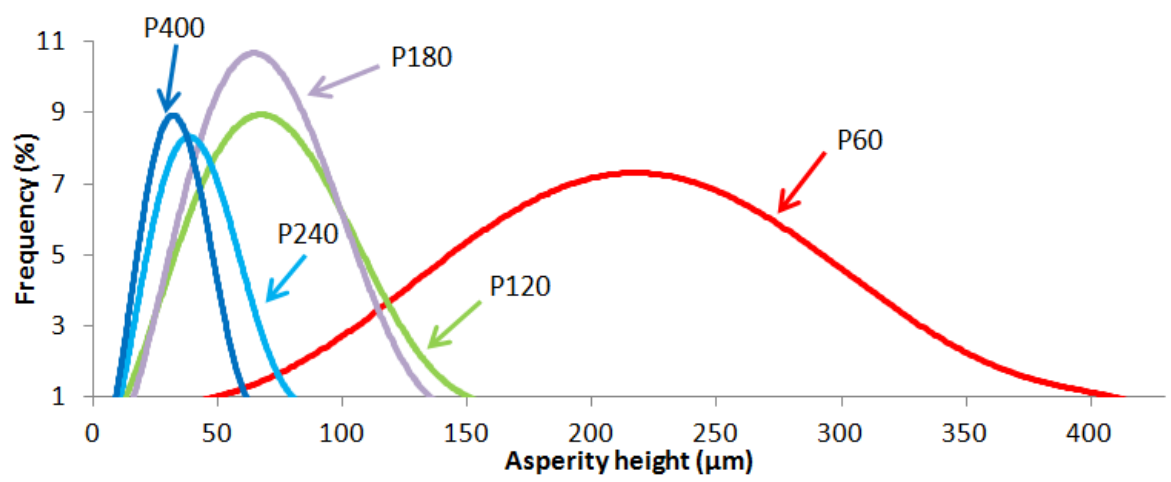

Figure 3. Distribution of the asperities height of abrasive clothes in the as-received condition.

Table 3. Asperities height distribution of abrasive clothes in the as-received condition

\begin{tabular}{lc}
\hline $\begin{array}{l}\text { Abrasive cloth } \\
\text { P-grad }\end{array}$ & $\begin{array}{c}\text { Mean of asperities } \\
\text { height distribution }(\mu \mathrm{m})\end{array}$ \\
\hline 400 & 34 \\
\hline 240 & 43 \\
\hline 180 & 72 \\
\hline 120 & 76 \\
\hline 60 & 222
\end{tabular}

* Technical contribution to the $2^{\text {nd }}$ International Brazilian Conference on Tribology - TriboBR 2014, November $3^{\text {rd }}$ to $5^{\text {th }}, 2014$, Foz do Iguaçu, PR, Brazil. 


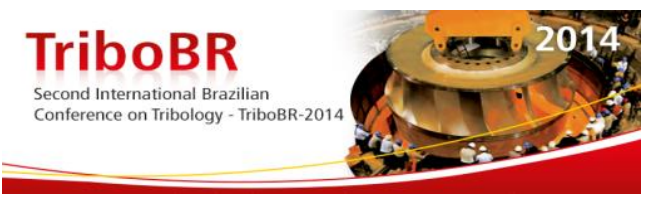

\section{RESULTS AND DISCUSSION}

\subsection{Wear Test}

The results obtained from dry condition abrasive wear test show that abraded wear volume for all materials increases with increasing normal applied load, abrasive paper grit size (Figure 4) and sliding distance (Figure 5).

Increase in normal load increases the contact stresses, depth of penetration of grit on the polymer surface, and hence the wear loss according to Srinath [6].

Both chemical family of elastomers behave in the same manner when increasing load, indeed the increase of the applied load magnify the difference between wear volume loss of materials.

Polyurethanes exhibit the best, with Pu3, and the worst, with Pu5, wear resistance for all grit size and applied load. Moreover Pu1, Pu2, Pu3 and Pu4 demonstrate to have a quite similar values of volume loss for grit size lesser than P120.

All Rubbers have an intermediate behavior between Pu5 and the rest of polyurethanes.

Rub5 is the less resistant wear material of rubber group.
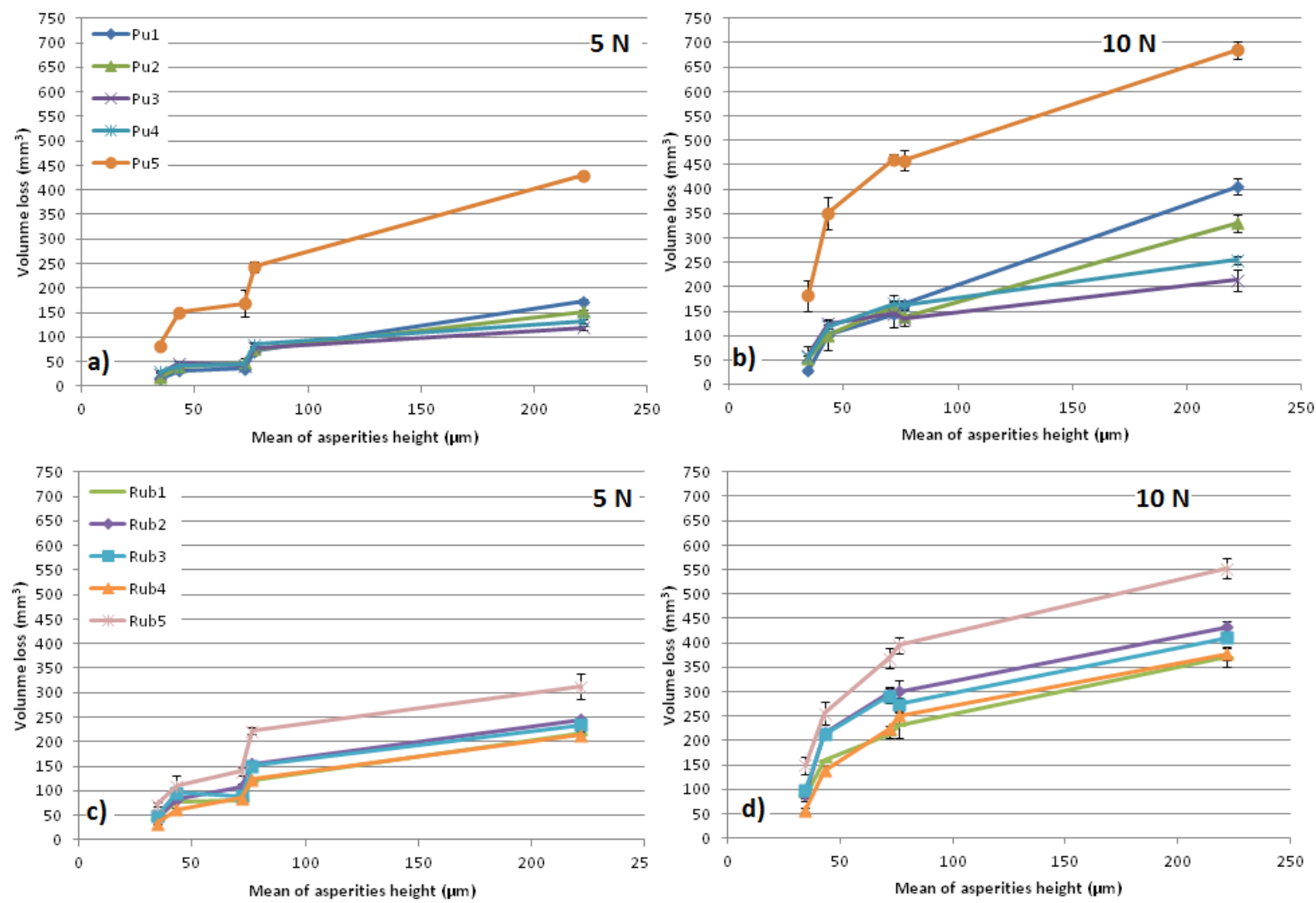

Figure 4. Variation of wear volume with mean of asperities height: Polyurethanes a) at $5 \mathrm{~N}$ and (b) at $10 \mathrm{~N}$; Rubbers (c) at $5 \mathrm{~N}$ and (d) at $10 \mathrm{~N}$.

Variation of wear volume with sliding distance was plotted for the P120 abrasive cloth and $5 \mathrm{~N}$ of applied load in Figure 5.

All materials present a linear correlation between volume loss and sliding distance as expected [8].

* Technical contribution to the $2^{\text {nd }}$ International Brazilian Conference on Tribology - TriboBR 2014, November $3^{\text {rd }}$ to $5^{\text {th }}$, 2014, Foz do Iguaçu, PR, Brazil. 

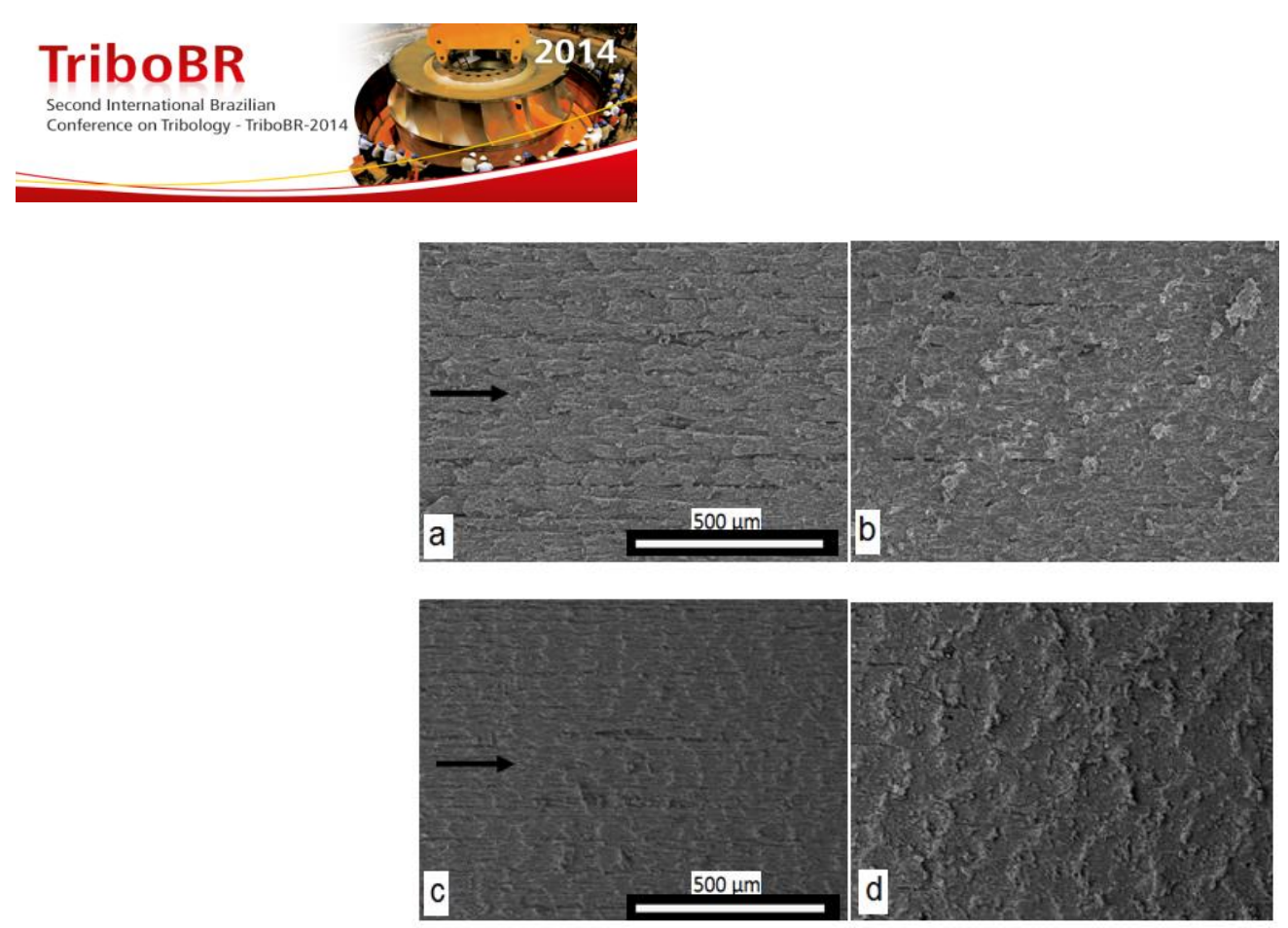

Figure 7. Scanning electron micrographs of worn surfaces at $5 \mathrm{~N}$ of applied load: (a)Pu2 (b)Rub1 for P120 abrasive cloth; (c)Pu2 (d)Rub1 for P180 abrasive cloth; Arrow shows sliding direction.

- At $10 \mathrm{~N}$ of applied load, the wear rises until it reaches a critical value of mean of asperities height around $60 \mu \mathrm{m}$ corresponding to a grit size between P240 and P120. SEM images after the tests made with P120, P180, P240 and P400 are presented in Figure 8. SEM images demonstrate how close worn surfaces, from tests made with P120 and P180, are. Here again mixed mechanisms were observed such as Schallamach waves and micro ploughing and micro cutting. The increase of load magnifies the said Schallamach waves.
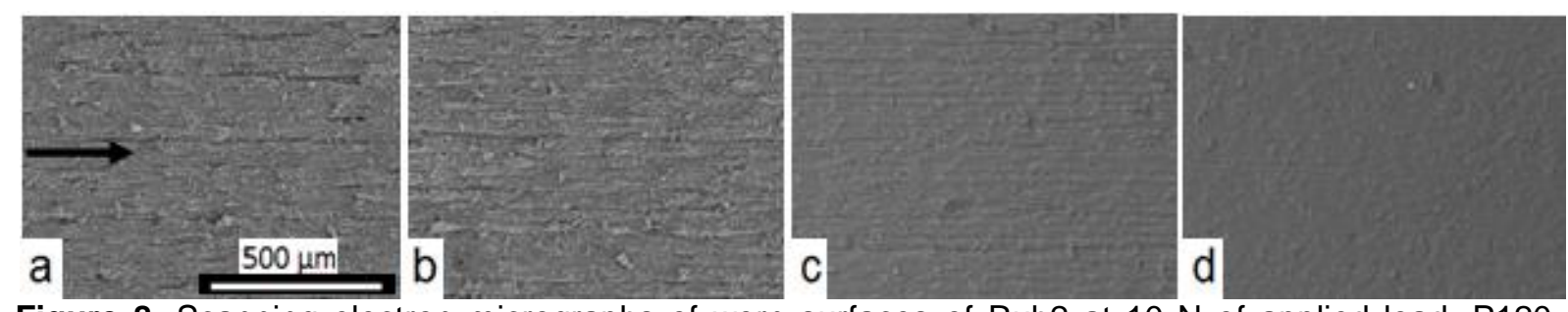

Figure 8. Scanning electron micrographs of worn surfaces of Rub2 at $10 \mathrm{~N}$ of applied load: P120, (b)P180, (c)P240 and (d) P400 abrasive cloth. Arrow shows sliding direction.

\subsection{Shore A Hardness}

In the same way that literature reported little correlation between wear and hardness for polymers [13, 14], poor correlation were also observed for all grit size and load (Figure 9).

In the rubber group, the softer rubber Rub5 presents the highest wear. The hardest rubber Rub3 has the second position in wear loss whereas the rubbers with intermediate hardness have sometimes the lowest wear loss.

In the polyurethane group, for approximately the same Shore A hardness opposite wear resistance was observed: PU5 has the highest volume loss of all materials, whereas polyurethanes PU1-PU4 have the lowest volume loss.

A probably environmental degradation should be a cause of the important wear of PU5 (tested in used condition without any historical information about working conditions). Indeed, a study of the effect of environmental degradation of polyurethanes in abrasive erosive condition revealed the importance of degradation mechanisms in wear of polyurethanes [15].

* Technical contribution to the $2^{\text {nd }}$ International Brazilian Conference on Tribology - TriboBR 2014, November $3^{\text {rd }}$ to $5^{\text {th }}$, 2014, Foz do Iguaçu, PR, Brazil. 

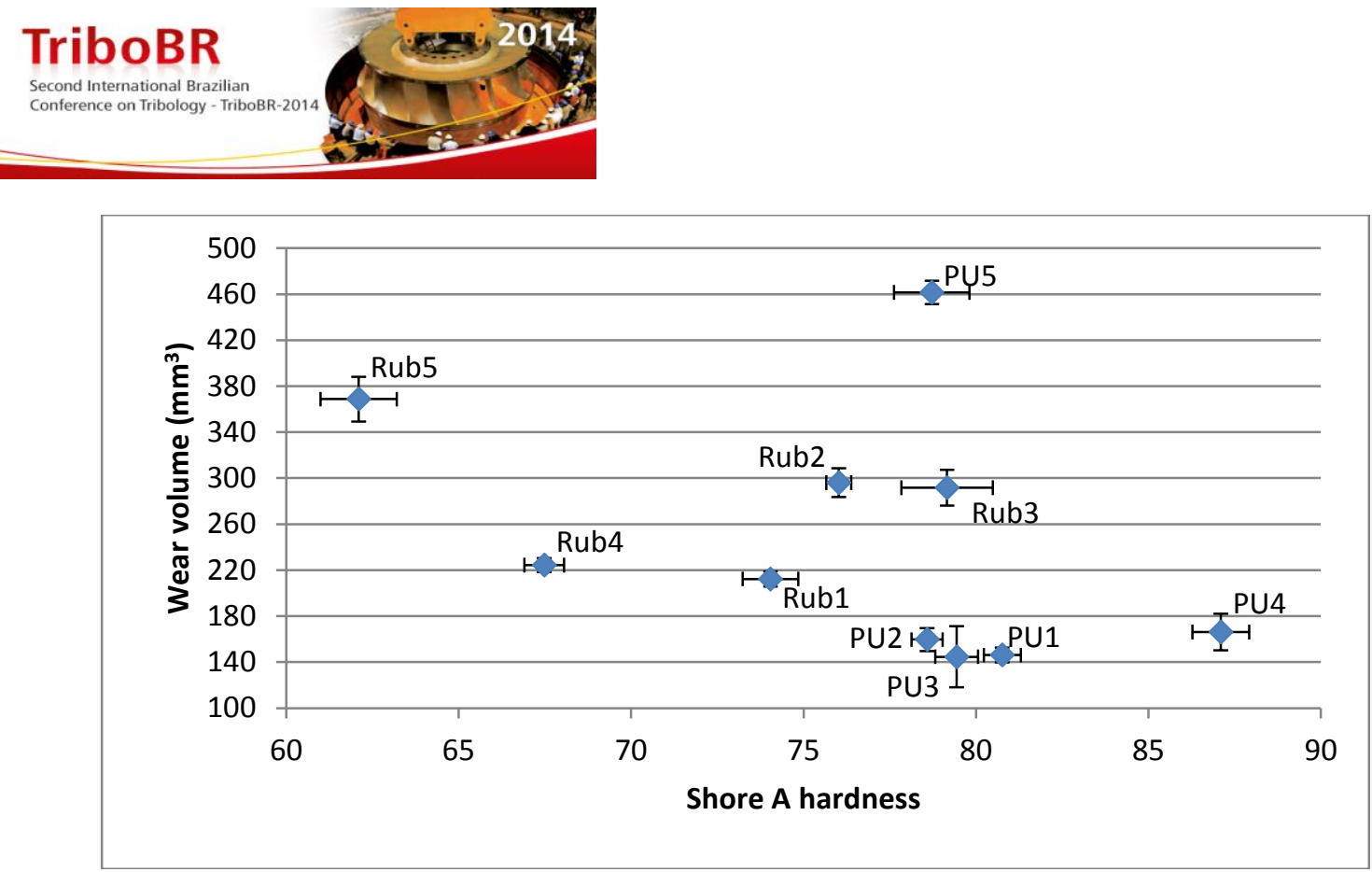

Figure 9. Variation of wear volume with hardness of sample pieces for an applied load of $10 \mathrm{~N}$ and grit sizeP180. Each data point corresponds to one material.

\section{CONCLUSION}

a) The mean of asperities height of abrasive cloth was used to correlate wear volume of elastomers with abrader coarseness.

b) Excluding PU5, Rubbers are less wear resistant than the polyurethanes in test conditions.

c) The abrasive wear volume increases in non-linear trend with increasing the abrasive grit size.

d) A transition in wear behavior between the P240 and P120 grit size was reported. After the transition corresponding to a mean of asperities height between 43 and $76 \mu \mathrm{m}$, the wear rate increases in a moderate way.

e) Poor correlation between wear and hardness was found.

f) Possible degradation effects of the received materials (mining environment) before testing should be responsible for the important wear of PU5.

\section{Acknowledgments}

We would also like to acknowledge the Laboratory of Fuel and Combustion (LCC) at UFES and in the Laboratory of Surface Phenomenon (LFS) at USP, for the good equipment and assistance. Thank you to the project VALE/INES for the opportunity to work in such good field that is wear in the Brazilian Industry.

\section{REFERENCES}

$1 \quad$ ASTM G40. Standard Terminology Relating to Wear and Erosion. 2013.

2 Hutchings IM. Tribology, Friction and Wear of Engineering Materials). Butterworth Heinemann; 1992.

3 Czichos H, Hanig KH. Tribologie Handbuch - Reibung und Verscleiß. Vieweg Verlag. 1992.

4 Eyre TS. Wear Characteristic of Metals. Trobilogy International. 1976; 9: 203-212.

5 Sare IR, Mardel JI, Hill AJ. Wear-resistant metallic and elastomeric materials in the mining and mineral processing industries-an overview. Wear. 2001; 250: 1-10.

\footnotetext{
* Technical contribution to the $2^{\text {nd }}$ International Brazilian Conference on Tribology - TriboBR 2014, November $3^{\text {rd }}$ to $5^{\text {th }}$, 2014, Foz do Iguaçu, PR, Brazil.
} 
6 Srinath G, Gnanamoorthy R. Two-body abrasive wear characteristics of Nylon clay nanocomposites -effect of grit size, load, and sliding velocity. Materials Science and Engineering. 2006; 435-436: 181-186.

7 Zaamout MS. Comparison of the Abrasive Wear Rate of Polymeric Materials Examined under Dry Condition. Journal of science, medicine, engineering. 2004; 16:49-65.

8 Unal H, Sen U, Mimaroglu A. Abrasive wear behavior of polymeric materials. Materials and Design. 2005; 26: 705-710.

9 Misra A, Finnie I. On the size effect in abrasive and erosive wear. Wear. 1981; 65: 359373.

10 Sin H, Saka N, Suh NP. Abrasive wear mechanism and the grit size effect. Wear. 1979; 55: 163-190.

11 ASTM D5963. Standard Test Method for Rubber Property_Abrasion Resistance (Rotary Drum Abrader). 2010.

12 Barquins M. Friction and wear of rubber-like materials. Wear. 1993; 160: 1-11.

13 Evans DC, Lancaster JK. The wear of polymers. Treatise on Materials science and Technology. 1979; 13: 85-139.

14 Budinski KG. Resistance to particle abrasion of selected plastics. Wear. 1997. 203-204: 302-309.

15 Zhang SW, He R, Wang D, Fan Q. Abrasive erosion of polyurethane. Journal of materials science. 2001. 36: 5037-5043.

* Technical contribution to the $2^{\text {nd }}$ International Brazilian Conference on Tribology - TriboBR 2014, November $3^{\text {rd }}$ to $5^{\text {th }}$, 2014, Foz do Iguaçu, PR, Brazil. 